\title{
Similarities and discrepancies between exacerbations of asthma and chronic obstructive pulmonary disease
}

\author{
Leonardo Fabbri, Bianca Beghé, Gaetano Caramori, Alberto Papi, Marina Saetta
}

Asthma is a chronic inflammatory disorder of the airways which causes recurrent episodes of wheezing, breathlessness, chest tightness, and cough, symptoms which are usually associated with reversible airflow limitation. ${ }^{12}$ This definition includes the recurrence of respiratory symptoms which might be otherwise classified as asthma exacerbations. However, the term asthma exacerbation is usually reserved for more severe and/or more persistent respiratory symptoms requiring a prolonged increase of current antiasthma medication. ${ }^{12}$ Chronic obstructive pulmonary disease (COPD) is defined as a progressive airflow limitation, mostly irreversible. ${ }^{3}{ }^{4}$ The term COPD includes patients with obstructive chronic bronchitis and/or pulmonary emphysema. ${ }^{34}$ Patients with moderate or severe persistent asthma may also have an irreversible component of airflow limitation, and thus they may also be included in the definition of COPD. ${ }^{3}$ The definition of COPD does not include exacerbations, ${ }^{3-5}$ even if exacerbations are the main cause of medical intervention and admission to hospital in these patients.

\section{Definitions of mild and severe exacerbations of asthma and COPD}

Recent guidelines provide classifications of exacerbations of asthma and COPD based on clinical parameters. ${ }^{1-46}$ Although these classifications may provide a useful tool for clinical studies, they are not standardised and they are rather cumbersome and difficult to use in clinical practice. The definitions derived from the literature are operational and vary with investigators. ${ }^{7-14}$ In this article we will try to provide some definitions to be subsequently used to discuss the pathogenesis and treatment of the two diseases.

Mild exacerbations of asthma may be defined as increased intensity or frequency of symptoms and/or worsened lung functionthat is, decreased forced expiratory flows or increased variability of peak expiratory flowthat force the patient either to change prescribed treatment and/or to seek medical attention. ${ }^{13}{ }^{14}$ The borderline between ongoing symptoms with frequent use of rescue medication and mild exacerbations may be difficult to identify in individual asthma patients as asthma may not be completely asymptomatic even after proper treatment in some subjects. Asthma exacerbations can be defined as severe if the patient has a lack of response to initial treatment, if the exacerbation has progressed quickly, or if the patient is at a high risk of asthma related death. ${ }^{215}$ Severe asthma exacerbations usually require admission to the emer- gency room and in some cases may be associated with acute respiratory failure. ${ }^{216-19}$

Mild exacerbations of COPD may be defined as increased breathlessness, possibly associated with increased cough and sputum production, that force the patient to seek medical attention outside the hospital. ${ }^{11}$ COPD exacerbations may be defined as severe when they are associated with acute respiratory failure. ${ }^{20}$ Severe COPD exacerbations frequently require admission to hospital. ${ }^{3}$

\section{Importance of exacerbations in asthma and COPD}

Exacerbations represent an important feature of the clinical manifestation and natural history of asthma and COPD. They represent the main cause of visits to general practitioners, emergency departments, and hospital admissions in affluent countries. ${ }^{21} 22$

Asthma exacerbations are usually associated with increased variability of peak flow, decreased forced expiratory flows and, in more severe patients, acute respiratory failure with marked abnormalities of the ventilation/ perfusion relationship and blood gas tensions. ${ }^{23-25}$ Most asthma exacerbations are mild and require only a change of prescribed therapy. Few asthma exacerbations are severe enough to require aggressive treatment with high dose bronchodilators and systemic glucocorticoids, and only occasionally result in acute respiratory failure requiring intubation and mechanical ventilation. ${ }^{16-19}$

The incidence and prevalence of asthma exacerbations are not well established, particularly because the definition and assessment of severity vary greatly between studies. For example, a recent study specifically designed to assess the effect on asthma exacerbations of a low $(100 \mu \mathrm{g}$ bid) or high $(400 \mu \mathrm{g}$ bid) dose inhaled budesonide alone or in combination with inhaled formoterol (12 $\mu \mathrm{g}$ bid) showed that more than $70 \%$ of mild to moderate asthmatic subjects develop an average of 40 mild exacerbations per year, and more than $40 \%$ of the same subjects develop an average of almost two severe exacerbations per year. ${ }^{14}$ By contrast, another study conducted in a similar population to compare the effect of a combination of beclomethasone and salmeterol with a higher dose of beclomethasone alone reported a much lower frequency of exacerbations, ${ }^{8}$ probably because exacerbations were not specifically investigated but were detected from the adverse events, and the criteria for severe exacerbations were more stringent (for example, hospital admission). Because of the heterogeneity of definition and classification of 
exacerbations, it is difficult to estimate the real incidence of exacerbations in asthmatic subjects. In particular, it is difficult to define the border between ongoing symptoms of asthma and asthma exacerbations, and it is unclear whether all asthmatic subjects develop recurrent exacerbations or whether there is a subgroup of "exacerbators" who develop recurrent exacerbations. ${ }^{79132627}$ It is important to define these patients to tailor a specific treatment. Unfortunately the characteristics of these patients are not clear. It has been suggested that sensitisation to some substances such as aspirin and other non-steroidal antiinflammatory agents is associated with more severe asthma and more frequent asthma exacerbations, ${ }^{28}$ but reliable data are lacking.

On average, patients with COPD experience exacerbations with a frequency of 0.1 per patient per month of observation. ${ }^{29}{ }^{30}$ In one recent study almost half of the patients with COPD had only one or no exacerbations per year, and only $30 \%$ had three or more exacerbations per year. ${ }^{31}$ Also, in COPD few of the exacerbations are severe enough to require aggressive treatment but these exacerbations more often result in acute respiratory failure requiring mechanical ventilation (nearly half in one study ${ }^{20}$ ), probably because they develop in a more compromised lung. The mortality of patients admitted to hospital with COPD exacerbations is about $14 \%$, a dramatic figure which exceeds current hospital mortality for myocardial infarction. ${ }^{32}$ The mortality of patients with COPD admitted to an intensive care unit (ICU) for exacerbations is $24 \%$, and for patients aged 65 years or older the mortality doubles in one year from $30 \%$ to $59 \%$. $^{33}$

Although symptoms of chronic bronchitis are associated with an increased risk of subsequent hospital admission because of COPD,${ }^{34}$ it is not known whether patients with COPD have more frequent acute chest illnesses than individuals of the same age without COPD. $^{35}$ It is more likely that there is a subgroup of COPD patients who develop recurrent exacerbations. ${ }^{31}{ }^{36}$ While mild COPD exacerbations are not associated with a significant change in lung function, ${ }^{37}$ moderate to severe COPD exacerbations are usually associated with a transient decrease in lung function. ${ }^{35}$ Interestingly, it has not yet been established whether exacerbations contribute to the excessive decline in forced expiratory volume in one second $\left(\mathrm{FEV}_{1}\right)$ which occurs in patients with COPD, ${ }^{38}$ or even to the shorter life expectancy of these patients. ${ }^{34}$

Overall asthma mortality at 5-34 years of age is approximately four deaths per million person years in the USA, ${ }^{39}$ a rate that is markedly lower than the mortality of COPD. In countries where asthma death rates can be separated, COPD is clearly associated with the highest mortality - for example, in Europe the rate is $10-50 / 100000$ person years. $^{4}$

Lack of understanding of the aetiology of asthma and COPD exacerbations

The aetiology of most asthma exacerbations is not established. Viral and, to a much lesser extent, bacterial respiratory infections occur in conjunction with most asthma exacerbations, particularly in children ${ }^{40}$ but also in adults. ${ }^{42-44}$ The precise mechanisms by which respiratory viruses, and particularly rhinoviruses, ${ }^{40}{ }^{44}$ may induce asthma exacerbations are largely unknown. ${ }^{45}$ Indeed, experimental rhinovirus infection may cause lymphocyte and eosinophil infiltration of the bronchial mucosa more persistently in asthmatic subjects, where it is accompanied by bronchial hyperreactivity. ${ }^{46}$ On the other hand, asthma is associated with upregulation of the ICAM-1 adhesion molecule in the airway mucosa which further increases during asthma exacerbations. ${ }^{48}$ ICAM-1 is the major surface receptor for rhinoviruse ${ }^{49}$ and thus an asthma exacerbation may theoretically increase the risk of the patient developing rhinovirus infections. Allergens, sensitising agents, and drugs may also trigger asthma exacerbations, sometimes severe ones. ${ }^{28}$ Another aspect of exacerbations that has not been explained is how it persists after a single exposure to a triggering agentfor example, how a single exposure to allergen or sensitising agent may be followed by an asthmatic response that may last for weeks. ${ }^{50} 51$

The aetiology of COPD exacerbations is even less well established. In fact, the role of bacterial infections, once believed to be the main cause of COPD exacerbations, still remains controversial ${ }^{52}$ and the role of viral infections is not so well established as it is in asthma. ${ }^{53}$ In addition to air pollution, ${ }^{54}$ other diseases more often associated with COPD than asthma may be responsible for COPD exacerbations including pulmonary hypertension and heart failure, ${ }^{55}$ airways plugging by excessive mucus, ${ }^{56}$ fatigue of the respiratory muscles, ${ }^{57} 58$ and thromboembolism..$^{50}$

\section{Pathology of exacerbations of asthma and COPD}

The pathology of exacerbations of asthma and COPD has not been adequately examined, probably because of the difficulty in performing invasive manoeuvres such as brushing, lavage, or biopsies in symptomatic patients. Some recent studies have included non-invasive examination of patients with an exacerbation by collecting spontaneous or induced sputum. These studies have provided new and interesting information.

Mild asthma exacerbations induced by tapering the dose of inhaled steroids are associated with sputum eosinophilia. ${ }^{61}$ By contrast, mild spontaneous asthma exacerbations are associated with eosinophilia in about half the subjects, the other half having a normal cell count. $^{62}$ In contrast to mild exacerbations, severe asthma exacerbations are associated with more prominent sputum neutrophilia. ${ }^{63}$ Interestingly, COPD exacerbations are associated with similar changes in the cell count in the sputum. In fact, mild COPD exacerbations are associated mainly with eosinophilia in sputum and in biopsy specimens, and severe COPD exacerbations are associated with sputum neutrophilia. ${ }^{376465}$ Thus, in the sputum at 
least the changes in inflammatory cells during exacerbations are similar in asthma and COPD.

In contrast to the few studies conducted in living patients, more studies have examined the pulmonary pathology of subjects who have died from asthma and COPD. Fatal asthma and COPD can be considered as extreme slopes of exacerbations of the diseases. Although several studies have described the pathology of fatal asthma, there is still limited information comparing the pathology of severe asthma with milder forms of the disease. As reported by Synek and co-workers, ${ }^{66}$ fatal asthma is associated with a greater numbers of eosinophils in the large airway wall and with a relative deficiency of $\mathrm{T}$ lymphocytes in the epithelium of the large airways compared with mild to moderate asthma. By contrast, inflammation in the small peripheral airways is similar in fatal asthma and in mild to moderate disease. The increased number of eosinophils is more marked in the larger airways of patients with fatal asthma than in those with non-fatal asthma which suggests that, when asthma is more severe, the degree of inflammatory response is more marked in the central airways. ${ }^{66}$ This is in agreement with the findings of Carroll et $a l^{67}{ }^{68}$ who found increased wall thickness in the large airways but not in the small airways of cases of fatal asthma compared with non-fatal asthma. This increase in thickness involved the inner wall, outer wall, smooth muscle, mucous glands, and cartilage. Sudden onset fatal asthma seems to be associated with fewer eosinophils and more neutrophils in the airway submucosa ${ }^{68}{ }^{69}$ and less mucus in the lumen of the airways. ${ }^{69} 70$

Curiously, studies on the pathology of COPD are very few. The largest study showed that death from COPD is associated with both emphysema and small airway inflammation. ${ }^{71}{ }^{72}$ When all the subjects were considered together, the most consistent relationship occurred between severe emphysema and degree of airflow obstruction, indicating that bronchiolar disease may not contribute significantly to chronic airflow obstruction. However, if only subjects with less severe emphysema were considered, several indices of bronchiolar inflammation correlated with the degree of airflow obstruction. Therefore, as pointed out by Gordon-Snider, ${ }^{73}$ the findings of Nagai and colleagues must be cautiously interpreted. Their data indicated that, when emphysema is moderate or severe, loss of elastic recoil becomes overwhelmingly important and thus it may mask the effects of bronchiolar disease on chronic airflow limitation. By contrast, when emphysema is mild, the contribution of bronchiolar abnormalities to chronic airflow limitation is evident. ${ }^{73}$

\section{Treatment of exacerbations of COPD and asthma}

The treatment of asthma exacerbations is reasonably standardised with inhaled $\beta_{2}$ agonists and systemic glucocorticoids as the cornerstone of pharmacological treatment with oxygen when required. This approach is based on several studies reported in the literature and recently reviewed, ${ }^{12} 157475$ and is consistently recommended by national and international guidelines. ${ }^{1215}{ }^{74}$ By contrast, the treatment of COPD exacerbations is much less established, probably because of the limited number of properly conducted studies. ${ }^{34}$ In fact, the treatment of asthma and COPD exacerbations is similar and is based on the administration of oxygen, short acting bronchodilators, and systemic glucocorticoids. ${ }^{1-4} 1574$

Short acting inhaled $\beta_{2}$ agonists are usually the preferred bronchodilators used in the treatment of both asthma and COPD exacerbations. $^{2-4157475}$ If there is no prompt response, the addition of an anticholinergic is recommended, particularly for COPD exacerbations, ${ }^{1-41574}$ even if supportive evidence for the effectiveness of the combination is rather controversial. ${ }^{76-79}$ Despite the consolidated clinical practice, the role of aminophylline in the treatment of asthma and COPD exacerbations also remains controversial, as most of the studies have shown that aminophylline increases the toxicity but not the efficacy of $\beta_{2}$ agonists, particularly in asthma. ${ }^{12748081}$

Even the role of systemic glucocorticoids, and particularly high dose systemic glucocorticoids, remains controversial in asthma exacerbations. ${ }^{82}$ Indeed, the current guidelines, based on existing evidence, recommend that all asthma exacerbations not responding to bronchodilators should be treated with systemic glucocorticoids. ${ }^{121574}$ By contrast, although common clinical practice, there is no firm recommendation for the use of systemic glucocorticoids in the treatment of COPD exacerbations. $^{3}{ }^{41283}$ A recent study has clearly shown the effectiveness of inhaled corticosteroids (fluticasone dipropionate) in preventing the episodes of severe exacerbations in patients with COPD. ${ }^{84}$

Antibiotics are rarely used and, in any case, are not recommended in the treatment of asthma exacerbations unless there is clearcut evidence of bacterial infections. ${ }^{12}{ }^{15} 74$ In contrast, antibiotics are very often used in the treatment of COPD exacerbations with the erroneous rationale that they are due to airway infections. ${ }^{57} \mathrm{~A}$ recent meta-analysis has shown a significant but marginal benefit of antibiotics $^{85}$ and has provided the rationale for the recommendation to consider them in the presence of some evidence of infection. ${ }^{34}$ However, a recent negative study has further weakened even this very cautious recommendation. ${ }^{86}$

Immunostimulating agents containing different species of bacteria frequently involved in lower respiratory infections have been tested in several clinical trials which have shown the ability of these compounds to reduce the number of acute exacerbations in patients with COPD ${ }^{87-89}$ A recent study has also shown the efficacy of the immunostimulating agent OM-85 BV on both patient morbidity and consumption of health care services. ${ }^{29}$ These compounds are thought to stimulate the immune system by promoting direct activation of lung macrophages with increased specific 
responses of $\mathrm{T}$ and $\mathrm{B}$ lymphocytes via the enhancement of antigen presentation mechanisms. ${ }^{90}$ Finally, even if long term treatment with mucoactive drugs has been successful in preventing chronic bronchitis exacerbations in patients with severe COPD, ${ }^{91}$ the role of mucolytic agents remains controversial and they are not recommended by current guidelines. $^{34}$

\section{Conclusion}

The definition, characterisation, and management of exacerbations of asthma and COPD still rely on clinical empirism with very little scientific support. Nonetheless, the diagnosis, assessment and management of asthma exacerbations is fairly straightforward whereas much less is known on the diagnosis, assessment, and management of COPD exacerbations. Despite the fact that both exacerbations of asthma and COPD are associated with acute airway inflammation, the cornerstone of treatment for both asthma and COPD exacerbations remains short acting bronchodilators while glucocorticoids have consistently been proved to be beneficial only in asthma exacerbations.

As often happens when reviewing the literature on a clinical topic, one finds more questions than answers. Exacerbations of asthma and COPD are certainly clear events in the mind of practising physicians. However, when one tries to provide simple concepts such as definition, classification, pathogenesis, or even a summary of the epidemiological data, one realises how little we know. Happily, in the last few years some epidemiological studies have been designed to measure the incidence and prevalence of asthma and COPD exacerbations, ${ }^{32}{ }^{92}$ and some pharmacological multicentre studies have been organised to investigate the effect of treatment on asthma and COPD exacerbations. ${ }^{1493-96}$ Additional studies are ongoing or have been initiated on the aetiopathogenesis and pathology of exacerbations. Thus, in a few years we should be able to understand more on this issue.

This study was supported by MURST (grants $60 \%$ and $40 \%$ ), Consorzio Ferrararicerche, Azienda Ospedaliera Sant'Anna, Ferrara; and European Community (Biomed 2 Research Project "ENrara; and European Community (Biomed 2 Res

1 Expert Panel Report 2. Guidelines for the diagnosis and management of asthma. National Institutes of Health, National Heart, Lung and Blood Institute, Publication No. 97-4051A, May 1997.

2 Sheffer AL, ed. Global initiative for asthma. NHLBI/WHO Workshop report. National Institutes of Health, National Workshop report. National Institutes of Health, National
Heart, Lung and Blood Institute, Publication No. 953659, January 1995.

3 Celli BR, Snider GL, Heffner J, et al. Standards for the diagnosis and care of patients with chronic obstructive pulmonary disease. Am $\mathcal{F}$ Respir Crit Care Med 1995;152(Suppl): S77-120.

4 Siafakas NM, Vermeire P, Pride NB, et al on behalf of the Task Force. Optimal assessment and management of chronic obstructive pulmonary disease (COPD). Eur Resp $\mathcal{F}$ 1995;8:1398-420.

5 Calverley P, Pride N. Chronic obstructive pulmonary disease London: Chapman and Hall Medical, 1995.

6 Ernst P, Fitzgerald JM, Spier S. Canadian asthma consensus conference summary of recommendations. Can Respir $\mathcal{f}$ 1996;3:89-100.

7 Fabbri L, Burge PS, Croonenborgh L, et al on behalf of an International Study Group. Comparison of fluticasone propionate with beclomethasone dipropionate in moderate to pionate with beclomethasone dipropionate in moderate to
severe asthma treated for one year. Thorax 1993;48:817-23.

8 Greening AP, Ind PW, Northfield M, on behalf of Allen and Greening AP, Ind PW, Northfield M, on behalf of Allen and
Hanburys Limited UK Study Group. Added salmeterol versus higher-dose corticosteroid in asthma patients with ymptoms on existing inhaled corticosteroid. Lancet 1994; $344: 219-24$

9 Juniper EF, Kline PA, Vanzieleghem MA, et al. Effect of ong-term treatment with an inhaled corticosteroid (budesonide) on airway hyperresponsiveness and clinical asthma in nonsteroid-dependent asthmatics. Am Rev Respir Dis 1990;142:832-6.

10 Pearlman DS, Chervinsky P, La Force C, et al. A comparison of salmeterol with albuterol in the treatment of mild-to-moderate asthma. N Engl F Med 1992;327:1420-5. nal airway inflammation in chronic bronchitis: characterization and correlation with clinical parameters. Am Rev Respir Dis 1989;140:1527-37.

12 Thompson WH, Nielson CP, Carvalho P, et al. Controlled trial of oral prednisone in outpatients with acute COPD exacerbation. Am ₹ Respir Crit Care Med 1996;154:407-12.

13 Woolcock A, Lundback B, Ringdal OLN, et al. Comparison of addition of salmeterol to inhaled steroids with doubling of addition of salmeterol to inhaled steroids with doubling 1996;153:1481-8

14 Pauwels R, Lofdahl CG, Postma DS, et al for the Formoterol and Corticosteroids Establishing Therapy (FACET) International Study Group. Effects of inhaled formoterol and budesonide on exacerbations of asthma. $N$ Engl f Med 1997;337:1405-11.

15 The British Thoracic Society, the National Asthma Campaign, the Royal College of Physicians of London in association with the General Practitioner in Asthma Group, the British Association of Accident and Emergency Medicine, the British Paediatric Respiratory Society and the Royal College of Paediatrics and Child Health. The British guidelines on asthma management: 1995 review and position statement. Thorax 1997;52(Suppl 1):S1-21.

16 LeSon S, Gershwin ME. Risk factors for intubation of adult asthmatic patients. $\mathcal{F}$ Asthma 1995;32:97-104.

17 LeSon S, Gershwin ME. Risk factors for asthmatic patients requiring intubation. II. Observations in teenagers. $\mathcal{f}$ Asthma 1995;32:379-89.

18 LeSon S, Gershwin ME. Risk factors for asthmatic patients requiring intubation. III. Observations in young adults. $\mathcal{F}$ Asthma 1996;33:27-35.

19 Pacht ER, Lingo S, St John RC. Clinical feature, management, and outcome of patients with severe asthma admitted to the intensive care unit. F Asthma 1995;32: 373-7

20 Connors AF, Dawson NV, Thomas C, et al for the SUPPORT Investigators. Outcomes following acute exacerbations of severe chronic obstructive lung disease. $\mathrm{Am} \mathcal{F}$ Respir Crit Care Med 1996;154:959-67.

21 Lung and Asthma Information Agency. Trends in hospital admissions for asthma. Factsheet 96/2.

22 Lung and Asthma Information Agency. Respiratory morbidity in general practice, 1971-1991. Factsheet 96/3

23 Chan-Yeung $M$, Chang JH, Manfreda J, et al. Changes in peak flow, symptom score, and the use of medications during acute exacerbations of asthma. Am $\mathcal{F}$ Respir Crit Care Med 1996;154:889-93.

24 Rodriguez-Roisin R. Pathophysiology. In: Brewis RAL, Corin B, Geddes DM, Gibson GJ, eds. Respiratory medicine. 2nd ed. London: WB Saunders, 1995: 1161-77.

25 Rodriguez-Roisin R. Acute severe asthma: pathophysiology and pathobiology of gas exchange abnormalities. Eur Respir f 1997;10:1380-91.

26 Adelroth E, Rosenhall L, Glennow C. High dose inhaled budesonide in the treatment of severe steroid-dependent asthmatics: a two year study. Allergy 1985;40:58-64.

27 Donahue JG, Weiss ST, Livingston JM, et al. Inhaled steroids and the risk of hospitalization for asthma. $\mathcal{F A M A}$ steroids and the risk

28 Picado C. Classification of severe asthma exacerbations: a proposal. Eur Respir F 1996;9:1775-8.

29 Collet JP, Shapiro S, Ernest P, et al. Effect of an immunostimulating agent on acute exacerbations and hospitalizations in patients with chronic obstructive pulmonary disease. Am $\mathcal{F}$ Respir Crit Care Med 1997;156:1719-24.

30 Anthonisen NR, Manfreda J, Warren CPW, et al. Antibiotic therapy in exacerbations of chronic obstructive pulmonary disease. Ann Intern Med 1987;106:196-204.

31 Miravitlles M, Mayordomo C, Sànchez-Agudo L, et al and EOLO group. Drug usage in acute exacerbations of COPD in general practice. Am 7 Respir Crit Care Med 1996; 153(Suppl):A825.

32 Fuso L, Incalzi RA, Pistilli R, et al. Predicting mortality of patients hospitalized for acutely exacerbated chronic patients hospitalized for acutely exacerbated chronic

33 Seneff MG, Douglas P, Wagner P, et al. Hospital and 1-year survival of patients admitted to intensive care units with acute exacerbation of chronic obstructive pulmonary disease. $\mathcal{F} A M A$ 1995;274:1852-7.

34 Vestbo J, Prescott E, Lange P and The Copenhagen City Heart Study Group. Association of chronic mucus hypersecretion with $\mathrm{FEV}_{1}$ decline and chronic obstructive pulmonary disease morbidity. Am f Respir Crit Care Med 1996;153:1530-5.

35 Fletcher CM, Peto R, Tinker C, et al. The natural history of chronic bronchitis and emphysema: an eigth-year study of early chronic obstructive lung disease in working men in London. New York: Oxford University Press, 1976: 272

36 Seemungal T, Paul EA, Donaldson GC, et al for the East London COPD Collaborative Group. Factors predisposing 51(Suppl 3):A19, S74. 
37 Saetta M, Di Stefano A, Maestrelli P, et al. Airway eosinophilia in chronic bronchitis during exacerbations.

38 Fletcher C, Peto R. The natural history of chronic airflow obstrution. BMF 1977;1:1645-8.

39 Arrighi HM. US asthma mortality: 1941 to 1989 . Ann Allergy Asthma Immunol 1995;74:321-6.

40 Johnston SL, Pattemore PK, Sanderson G, et al. Community study of role of viral infections in exacerbations of asthma in 9-11 year old children. BMf 1995;310:12258 .

41 Johnston SL, Pattemore PK, Sanderson G, et al. The relationship between upper respiratory infections and hospital admission for asthma: a time-trend analysis. $\mathrm{Am} \mathcal{F}$ Respir Crit Care Med 1996;154:654-60.

42 Corne JM, Smith S, Schreiber J, et al. The role of rhinovirus in exacerbations of asthma in adults. Am $\mathcal{F}$ Respir Crit Care Med 1997;155(Suppl):A63

43 Sokhandan M, McFadden ER, Huang YT, et al. The contribution of respiratory viruses to severe exacerbations of asthma in adults. Chest 1995;107:1570-5.

44 Nicholson KG, Kent J, Ireland DC. Respiratory viruses and exacerbations of asthma in adults. BMF 1993;307:982-6.

45 Corne JM, Holgate ST. Mechanisms of virus induced exacerbations of asthma. Thorax 1997;52:380-9.

46 Fraenkel DJ, Bardin PG, Sanderson G, et al. Lower airways inflammation during rhinovirus colds in normal and in asthmatics subjects. Am f Respir Crit Care Med 1995;151: 879-86.

47 Calhoun WJ, Dick EC, Schwartz LB, et al. A common cold virus, rhinovirus 16 , potentiates airway inflammation after segmental antigen bronchoprovocation in allergic subjects. f Clin Invest 1994;94:2200-8.

48 Bloemen PGM, Henricks PAJ, Nijkamp FP. Cell adhesion molecules and asthma. Clin Exp Allergy 1997;27:128-41.

49 Staunton DE, Merluzzi VJ, Rothlein R, et al. A cell adhesion molecule, ICAM-1, is the major surface receptor for rhinoviruses. Cell 1989:56:849-53.

50 Perrin B, Cartier A, Ghezzo H. Reassesment of the temporal patterns of bronchial obstruction after exposure to occupational sensitizing agents. F Allergy Clin Immuno 1991;87:630-9.

51 Sterk PJ, Fabbri LM, Quanjer PhH, et al. Airway responsiveness: standardized challenge testing with pharmacological, physical and sensitizing stimuli in adults. Report of Working Party, Standardization of Lung Function Tests, European Community for Steel and Coal, Official Statement of the European Respiratory Society. Eur Respir F 1993;6(Suppl 16):53-83.

52 Fagon JY, Chastre J. Severe exacerbations of COPD patients: the role of pulmonary infections. Semin Respir

53 Hogg JC, Hegele RG. Viral infection as a precipitating factor. In: Derenne J-P, Whitelaw WA, Similowski T, eds. Acute respiratory failure in chronic obstructive pulmonary disease. Lung Biology in Health and Disease, Vol 92. New York: Marcel Dekker, 1996: 319-35.

54 Anderson HR, Spix C, Medina S, et al. Air pollution and daily admissions for chronic obstructive pulmonary disease in six European cities: results from the APHEA project. Eur Respir f 1997;10:1064-71.

55 Dinh-Xuan AT, Higenbottam TW. Pulmonary vascular reactivity in acute respiratory failure of chronic obstructive pulmonary disease. In: Derenne J-P, Whitelaw WA, Similowski T, eds. Acute respiratory failure in chronic obstructive pulmonary disease. Lung Biology in Health and Disease, tive pulmonary disease. Lung Biology in Health and

56 King M, Rubin BK. Mucus physiology and pathophysiology: therapeutic aspects. In: Derenne J-P, Whitelaw WA, Similowski T, eds. Acute respiratory failure in chronic obstructive pulmonary disease. Lung Biology in Health and Dise

57 Grassino AE, Begin P. Role of respiratory muscle dysfunction in ventilatory failure. In: Derenne J-P, Whitelaw WA, Similowski T, eds. Acute respiratory failure in chronic obstructive pulmonary disease. Lung Biology in Health and Disease, Vol 92. New York: Marcel Dekker, 1996: 65-78.

58 Barberà JA, Roca J, Ferrer A, et al. Mechanisms of worsening gas exchange during acute exacerbations of chronic obstructive pulmonary disease. Eur Respir $\mathcal{F}$ 1997;10:1285-91.

59 Pariente R, Whitelaw WA. Thromboembolic disease as a precipitating factor. In: Derenne J-P, Whitelaw WA, precipitating factor. In: Derenne J-P, Whitelaw WA, tive pulmonary disease. Lung Biology in Health and Disease, tive pulmonary disease. Lung Biology in Health and

60 Worley BD, Peacock M, Burke B, et al. The incidence of deep venous thrombosis in patients with chronic obstructive pulmonary disease exacerbation. Am f Respir Crit Care Med 1997;155(Suppl):A594.

61 Gibson PG, Wong JO, Hepperle MJE, et al. A research method to induce and examine a mild exacerbation of asthma by withdrawal of inhaled corticosteroid. Clin Exp Allergy 1992;22:525-32.

62 Turner MO, Hussack P, Sears MR, et al. Exacerbations of asthma without sputum eosinophilia. Thorax 1995;50: 1057-61.

63 Fahy JV, Kim KW, Liu J, et al. Prominent neutrophilic inflammation in sputum from subjects with asthma exacerbation. F Allergy Clin Immunol 1995;4:843-52.

64 Maestrelli P, Saetta M, Di Stefano A, et al. Comparison of leukocyte counts in sputum, bronchial biopsies and bronchoalveolar lavage. Am f Respir Crit Care 1995;152: 1926-31.
65 Piattella M, Maestrelli P, Saetta M, et al. Sputum eosinophilia during mild exacerbations and sputum neuRespir Crit Care Med 1996;153(Suppl):A822.

66 Synek M, Beasley R, Frew AJ, et al. Cellular infiltration of the airways in asthma of varying severity. Am $\mathcal{F}$ Respir Crit Care Med 1996;154:224-30.

67 Carroll N, Elliot J, Morton A, et al. The structure of large and small airways in nonfatal and fatal asthma. Am Rev Respir Dis 1993;147:405-10.

68 Carroll N, Cooke C, James A. The distribution of eosinophils and lymphocytes in the large and small airways of asthmatics. Eur Respir f 1997;10:292-300.

69 Sur S, Crotty TB, Kephart GM, et al. Sudden-onset fatal asthma: a distinct entity with few eosinophils and relatively more neutrophils in the airway submucosa? Am Rev Respir Dis 1993;148:713-9.

70 Reid LM. The presence or absence of bronchial mucus in fatal asthma. F Allergy Clin Immunol 1987;80:415-6.

71 Nagai A, West WW, Paul JL, et al. The National Institute of Health Intermittent Positive-Pressure Breathing Trial. Pathology studies. Am Rev Respir Dis 1985;132:937-45.

72 Nagai A, West WW, Thurlbeck WM. The National Institutes of Health Intermittent Positive-Pressure Breathing Trial. Pathology studies, II: Correlation between morphologic findings, clinical findings and evidence of expiratory air-flow obstruction. Am Rev Respir Dis 1985;132:946-53.

73 Snider GL. Chronic obstructive pulmonary disease: a continuing challenge. Am Rev Respir Dis 1986;133:942-4. 74 Beveridge RC, Grunfeld AF, Hodder RV, et al for the CAEP/CTS Asthma Advisory Committee. Guidelines for the emergency management of asthma in adults. Can Med Assoc F 1996; 155:25-37.

75 Cochrane GM. Acute severe asthma: oxygen and high dose $\beta$ agonist during transfer for all. Thorax 1995;50:1-2.

76 Fitzgerald JM, Grunfeld A, Pare PD, et al and the Canadian Combivent Study Group. The clinical efficacy of combination nebulized anticholinergic and adrenergic bronchodilators vs nebulized adrenergic bronchodilator alone in acute asthma. Chest 1997;111:311-5.

77 McFadden ER Jr, El Sanadi N, Strauss L, et al. The influence of parasympatholytics on the resolution of acute attacks of asthma. Am $\mathcal{F}$ Med 1997;102:7-13.

78 Garrett JE, Town GI, Rodwell P, et al. Nebulized salbutamol with and without ipratropium bromide in the treatment of acute asthma. F Allergy Clin Immunol 1997;100:165-70.

79 Moayyedi P, Congleton J, Page RL, et al. Comparison of nebulised salbutamol and ipratropium bromide with salbutamol alone in the treatment of chronic obstructive pulmonary disease. Thorax 1995;50:834-7.

80 Murphy DG, McDermott MF, Rydman RJ, et al. Aminophylline in the treatment of acute asthma when $\beta_{2}-$ adrenergic agents and steroids are provided. Arch Intern Med 1993;153:1784-8

81 Rice KL, Leatherman JW, Duane PG, et al. Aminophylline for acute exacerbations of chronic obstructive pulmonary disease. Ann Intern Med 1987;107:305-9.

$82 \mathrm{McF}$ adden ER Jr. Role of glucocorticoids in the therapy of acute asthma. In: Schleimer RP, Busse WW, O'Byrne PM, eds. Inhaled glucocorticoids in asthma: mechanisms and clinical actions. Lung Biology in Health and Disease, Vol 97. New York: Marcel Dekker, 1997: 507-19.

83 Niewoehner DE, Erbland ML. Systemic corticosteroids in COPD: an unresolved clinical dilemma. Chest 1996;110: 867-9.

84 Paggiaro PL, Dahle R, Bakran I, et al. Multicenter randomized placebo controlled trial of inhaled fluticasone propionate in patients with COPD. Lancet 1998;351:773-80.

85 Saint S, Bent S, Vittinghoff E, et al. Antibiotics in chronic obstructive pulmonary disease exacerbations. A metaanalysis. FAMA 1995;273:957-60.

86 Sachs AP, Koeter GH, Groenier KH, et al. Changes in symptoms, peak expiratory flow, and sputum flora during reatment with antibiotics of exacerbations in patients with chronic obstructive pulmonary disease in general practice. Thorax 1995;50:758-63.

87 Xinogalos S, Duratsoa D, Varonos D. Clinical effectiveness of Broncho-Vaxon in patients with chronic bronchitis. Int $\mathcal{F}$ Immunother 1993;9:135-42.

88 Maestroni GJM, Lose GA. Clinical and immunibiological effects of an orally administered bacterial extract. Int $\mathcal{F}$ Immunopharmacol 1984;6:111-7.

89 Keller R. Multicentre double blind study of the BronchoVaxom in chronic bronchitis. Prax Klin Pneumol 1984;38: 225-8.

90 Mauel J, Van Pharm T, Kreis B, et al. Stimulation by a bacterial extract (Broncho-Vaxom) of the metabolic and functional activities of murine macrophages. Int $\mathcal{f}$ Immunopharmacol 1989;11:636-45.

91 The AMETHIST Italian Study Group. Efficacy of 12 month therapy with oral ambroxol in preventing exacerbations in patients with chronic bronchitis. Double-blind randomized, multicenter placebo controlled study. Chest 1997; 112(Suppl 3):22S.

92 Martinez FD, Wright AL, Taussig LM, et al and the Group Health Medical Associates. Asthma and wheezing in the first six years of life. N Engl F Med 1995;332:133-8.

93 Anthonisen NR, Connett JE, Kiley JP, et al for the Lung Health Study Research Group. Effects of smoking intervention and the use of an inhaled anticholinergic bronchodilator on the rate of decline of $\mathrm{FEV}_{1}$ : the Lung Health Study. FAMA 1994;272:1497-505. 
94 Pauwels RA, Lofdahl CG, Pride NB, et al. European Respiratory Society study on chronic obstructive pulmonary disease (EUROSCOP): hypothesis and design. Eur Respir $\mathcal{F}$

95 Sherwood Burge P, Calverley P, for the Isolde Study Group. Inhaled steroids in obstructive lung disease in Europe, the
Isolde trial; protocol and progress. Am $\mathcal{F}$ Respir Crit Care Med 1994;149(Suppl):A312.

, Vestbo J, Lange P, et al. The Copenhagen City Lung Study. A clinical trial of inhaled corticosteroids in COPD: design and progress. Am F Respir Crit Care Med 1997;155(Suppl):A590. 